\title{
Interpretacje
}

\section{W.G. Sebald, podmiot romantyczny}

Marek Wilczyński

TEKSTY DRUGIE 2019, NR 3, S. 270-282

DOI: $10.18318 /$ td.2019.3.16 | ORCID: 0000-0002-6486-6001

$\mathbf{N}$ a dobrą sprawę nie trzeba nawet czytać tekstów W.G. Sebalda - wystarczy na nie popatrzeć, żeby ich autora uznać za figurę romantyczną bądź przynajmniej o wyraźnie romantycznej proweniencji. Pojawia się w przestrzeni realnej i wyimaginowanej zamaskowany - „larvatus prodeo” - pod różnymi postaciami, w różnych słownych przebraniach i wcieleniach: zaszyfrowany jako W.G. (Willibald Georg), Max (imię „prawdziwe”) lub św. Sebald (wspomniany w Pierścieniach Saturna sarkofag w Norymberdze' ${ }^{1}$ ), rozpięty między Niemcami a Anglią, ale także Włochami i Korsyką. Znajoma ponowoczesna gra tożsamości i różnicy obejmuje zarówno niezaprzeczalny ludzki konkret - autorski podpis obecny na okładkach książek, jak i wspomnienia przyjaciół (skąd inaczej wiedzielibyśmy, że „Max”?), wreszcie równie dzisiaj, po przedwczesnej śmierci „Maxa”, rzeczywistego narratora Czuję. Zawrót głowy, Pierścieni Saturna, pierwszej części

\section{Marek}

Wilczyński - prof. dr hab., pracownik Ośrodka Studiów Amerykańskich Uniwersytetu Warszawskiego. Zainteresowania badawcze: literatura amerykańska i polska XIX wieku, proza polska XX wieku, komparatystyka literacka. Kontakt: m.wilczynski2@ uw.edu.pl

1 W.G. Sebald Pierścienie Saturna, przeł. M. Łukasiewicz, W.A.B., Warszawa 2009, s. 101-103. 
Campo Santo, a może również Austerlitza. Na plan pierwszy wysuwa się zatem par excellence romantyczna kwestia samoustanowienia (się) podmiotu, wzięta w dyskretny, autoironiczny nawias fichteańska problematyka mocnego „ja”: podmiot istnieje, a raczej ustawicznie staje się, ponieważ mówi, stwarza i powiela samego siebie. Po drugie, natychmiast rozpoznawalna po rytmie proza Sebalda to efekt typowo romantycznego mieszania i „mącenia” gatunków: opowieści biograficznej, relacji z wędrówki lub podróży, eseju, wspomnienia. Po trzecie, proza ta przybiera najczęściej znaną z kręgu „Athenaeum” formę fragmentaryczną, podkreśloną przerywnikami w postaci ilustracji, najczęściej fotografii, czasami prawdomównych, kiedy indziej przewrotnie mylących.

W eseju Próba restytucji pisarz podsuwa czytelnikowi umieszczony jakby na marginesie tekstów obszerniejszych krótki autokomentarz: „Był maj 1976, kiedy po raz pierwszy wysiadłem na dworcu Bonatza, zasłyszawszy od kogoś, że w Stuttgarcie przy Reinsburgsstrasse mieszka malarz Jan Peter Tripp, z którym swego czasu chodziłem do szkoły w Oberstdorfie. Zachowałem w pamięci wizytę $u$ niego, bo wraz z podziwem, jaki natychmiast wzbudziła we mnie praca Trippa, przyszło mi do głowy, że sam też miałbym chęć robić coś innego niż prowadzenie wykładów i seminariów. Tripp ofiarował mi wówczas jeden ze swoich sztychów i z tym sztychem, na którym widnieje chory psychicznie sędzia Daniel Paul Schreber z pająkiem w czaszce cóż jest okropniejszego niż nieustannie snujące się w nas myśli? - z tym sztychem wiąże się wiele $\mathrm{z}$ tego, co potem napisałem, także pod względem metody zachowywania ścisłej perspektywy historycznej, cierpliwego rytowania oraz łączenia w manierze nature morte rzeczy pozornie od siebie bardzo odległych"2.

Tak zbudowane są tomy Czuję. Zawrót głowy i Pierścienie Saturna, a nawet Austerlitz, obszerna powieść pod znakiem tytułowego protagonisty, niczym Don Kichot czy Robinson Crusoe. Pierwsza część Czuje. Zawrót głowy, Beyle albo osobliwy akt miłości, krąży oczywiście wokół Stendhala, w drugiej, All'estero, podróżujemy wraz z narratorem z Anglii na kontynent; najpierw do Wiednia, gdzie spotyka się on z dawnym, chorym psychicznie kolegą Ernstem Herbeckiem, potem do Wenecji i Werony (w Wenecji erudycyjny ekskurs o Casanovie), siedem lat później (latem 1987) znów do Werony i dalej do Limone, gdzie „W.G. Sebald”, co niezbicie wynika z opatrzonego nazwiskiem zdjęcia,

2 W.G. Sebald Campo Santo, przeł. M. Łukasiewicz, W.A.B., Warszawa 2014, s. 285. 
traci paszport, po czym wyrabia nowy dokument w niemieckim konsulacie w Mediolanie, jeszcze raz do Werony... i na koniec ponownie do Wiednia, ale tylko po to, aby natknąć się tam metaforycznie na Kafkę. To Kafce i jego podróżom poświęcona jest część trzecia, Dr K. na kąpielach w Rivie, a cześć czwarta, ostatnia, pod włoskim tytułem Il ritorno in patria, czyli „Powrót do ojczyzny", traktuje o wizycie narratora w niemieckiej miejscowości W. (W.G. Sebald urodził się w miasteczku Wertach im Allgäu, ale jakie to ma znaczenie?). W Pierścieniach Saturna, liczących rozdziałów aż dziesięć, zmiany scenerii i tematyki są tak liczne i raptowne, że rysowanie mapy tekstu mija się z celem, chociaż w zasadzie, dla ułatwienia, cały czas znajdujemy się w Anglii. Dygresje prowadzą w różnych kierunkach w przestrzeni i w czasie - jedynie wiodący je podmiot stanowi zwornik labiryntowej kompozycji,jak przystało na wszechogarniający podmiot romantyczny.

To właśnie podmiot i jego ontologiczny status oraz postrzeganie jest punktem wyjścia i zarazem dojścia w prozie Sebalda. W L'absolu littéraire, studium poświęconym jenajskiemu romantyzmowi, Philippe Lacoue-Labarthe i Jean-Luc Nancy deklarują:

Trzeba rozpocząć od problematyki podmiotu, który jest nieprzedstawialny dla samego siebie, oraz wykluczenia wszelkiego substancjalizmu, aby zrozumieć to, co romantyzm otrzymał [w spadku od Kanta - przyp. M.W.] nie tyle jako dziedzictwo, ile jako swój „własny” najtrudniejszy i być może nierozwiązywalny problem. Wraz z chwilą, kiedy podmiot zostaje opróżniony z wszelkiej substancji, czysta forma, jaką przyjmuje, zostaje zredukowana wyłącznie do funkcji jednoczenia bądź syntetyzowania. Transcendentalna wyobraźnia, Einbildungskraft, jest funkcją, która musi nadać formę (bilden) tej jedności, musi ją uformować jako Bild, jako przedstawienie lub obraz, innymi słowy, jako fenomen, jeżeli przez fenomen rozumieć to, co nie należy ani do porządku zjawisk („tylko zjawisk”), ani wyglądów, Erscheinung w mocnym sensie tego słowa, na którym można ufundować ontologię „czegoś, co jest [tym właśnie - przyp. M.W.]”. A zatem transcendentalna wyobraźnia formuje czy też konstruuje przedmiot, który może być ujęty przez intuicję a priori, ale nie można go rozpoznać w pojęciu eidos, Idei, pierwotnej i rzeczywistej formy samego rozumu. [...] Rezultatem jest poznanie w granicach możliwego doświadczenia a priori, lecz poznanie to nie może doprowadzić do restytucji podmiotu i zadowolić pod tym względem nikogo z wyjątkiem tych, którym wystarczy 
„podmiot poznania zjawisk", oraz ich następców, poczynając od pozytywizmu poprzez pragmatyzm do strukturalizmu i ostatnich lat bieżącego [tj.XX - przyp. M.W.] stulecia. ${ }^{3}$

Takim właśnie podmiotem obdarzonym „transcendentalną wyobraźnią" jest „Sebald” Sebalda, dokonujący w tekstach bezustannej syntezy fenomenów, w tym również obrazów w znaczeniu unaocznień, przedstawień wizualnych. Możemy o tym przeczytać w Pierścieniach Saturna, gdy narrator opowiadający historię życia Edwarda FitzGeralda, słynnego tłumacza na angielski Rubajatów Omara Chajjama, przenosi się nagle w wyobraźni z jego posiadłości w Boulge do „rezydencji u stóp Slieve Bloom Mountains w Irlandii, gdzie przed laty krótko [gościł - przyp. M.W.]”: „Całe umeblowanie pokoju składało się ze stołu, krzesła i wąskiego żelaznego łóżka, jakie daje się złożyć i rozłożyć paroma ruchami rąk, z rodzaju tych, które kiedyś służyły wyższym szarżom w czasie kampanii wojennych. Ilekroć w ciągu najbliższych dni spoczywałem na tym łóżku, moja świadomość poczynała rozpadać się na obrzeżach i niekiedy nie umiałbym powiedzieć, skąd się tu wziąłem i gdzie w ogóle jestem. Wciąż wydawało mi się, że leżę w gorączce w jakimś lazarecie. Z dworu słychać było przeszywający krzyk pawi, ale moja wyobraźnia nie podsuwała mi widoku podwórza, gdzie ptaki sadowiły się na stosie składowanych tam od lat rupieci, lecz pole bitwy gdzieś w Lombardii, nad którym krążą sępy, a wokół spustoszony przez wojnę kraj. Wojska dawno temu pociągnęły dalej. Tylko ja leżałem, raz po raz zapadając w omdlenie, w doszczętnie splądrowanym domu"4.

Tu, w tym pokoju, „Sebald” przeistacza się mimowolnie w „Stendhala” z Czuję. Zawrót głowy, rannego uczestnika kampanii włoskiej Napoleona, zacierając zarazem granicę między kontrolującym opowieść podmiotem a jednym z jej przedmiotów, przez co chwilowo pogłębia się ontologiczny chaos, skądinąd wywoływany już co pewien czas uprzednio przeskokami od relacji o wędrówce „Sebalda” przez hrabstwo Suffolk latem roku 1992 do różnych przestrzeni, w których pojawiają się przyciągający jego uwagę bohaterowie: Apollo Korzeniowski i jego syn Konrad, bojownik o niepodległość Irlandii Roger Casement, ostatni cesarz Chin Xianfeng, poeta Charles Algernon

3 P. Lacoue-Labarthe, J.-L. Nancy The Literary Absolute. The Theory of Literature in German Romanticism, trans. by P. Barnard, Ch. Lester, SUNY Press, Albany 1988, s. 30-31 [przekład polski - M.W.]

W.G. Sebald Pierścienie Saturna, s. 241-242. 
Swinburne, Chateaubriand i pochowany w kościele St. Peter Mancroft w Norwich, gdzie znajduje się University of East Anglia - miejsce pracy W.G. Sebalda, Sir Thomas Browne. Czasami bywa więc tak, jak w romantycznych peregrynacjach Williama Wordswortha po „Lake District”, trzymających się na ogół topografii realnej, lecz niekiedy zbaczających w wyobraźni poety w Alpy, do Bellagio nad jeziorem Como lub nad Jezioro Genewskie ${ }^{5}$, a czasami czytelnik trafia na Syberię, do Krakowa, Irlandii, Pekinu albo znienacka na moment pod nienaruszoną Świątynię Jerozolimską, z której ocalała przecież tylko Ściana Płaczu. Dodatkowo wszystkie te osoby i obszary podtrzymywane są we wspólnej tekstowej rzeczywistości przez fotografie epatujące widzialnym konkretem, upewniające czytelnika o realnym przynajmniej niegdyś, jeżeli nie teraz, istnieniu przywoływanych kolejno historycznych postaci.

Wykorzystywanie zdjęć w roli ilustracji to może najbardziej uderzająca cecha twórczości literackiej Sebalda, autora „książek z obrazkami”. O dwuznacznym statusie fotografii i związanych z nią zagrożeniach dla rzeczy oraz ludzi fotografowanych wypowiada się on w eseju Kafka i kino, znowu poniekąd pisząc również i o sobie, o własnej metodzie tworzenia tekstu: „Jeśli w czasach romantyzmu, kiedy to po raz pierwszy dał o sobie znać lęk przed aparatami, sobowtór był jeszcze upiornym zjawiskiem wyjątkowym, to teraz jest wszechobecny. Zasadą całej techniki fotograficznego odwzorowywania jest w końcu doskonałe podwojenie bądź potencjalnie nieskończone powielanie modela. Wystarczy wziąć do ręki jedną z tych stereoskopowych kart i już widać wszystko podwójnie. A ponieważ podobizna trwała, choć model dawno już przeminął, nasuwała się też niemiła intuicja, że modelom, człowiekowi i przyrodzie, przysługuje niższy stopień autentyzmu niż kopii, że kopia podważa oryginał, inaczej - że ktoś, kto spotyka swego sobowtóra, sam czuje się unicestwiony"6.

Passus ten rzuca dziwne światło na książki Sebalda - raz jeszcze z rozmysłem używam rzeczownika „książki”, ponieważ chodzi zarówno o tekst, jak i ilustracje. Oto z jednej strony status fikcyjnej prozy ilustrowanej, a więc z pozoru ontologicznie „wzmocnionej”, zaczyna się załamywać: zamiast zbliżać ją lub nawet bez reszty godzić z rzeczywistością, zdjęcia i ryciny wydają się ją od rzeczywistości oddalać. Nie należy im zresztą zanadto ufać. Na stronicy 33 Czuję. Zawrót głowy znajdujemy pozbawiony twarzy fragment zdjęcia mężczyzny w trzyczęściowym garniturze, pod krawatem, z kapeluszem w ręku.

5 Por. W. Wordsworth Selected Prose, ed. by J.O. Hayden, Penguin, Harmondsworth 1988, s. 69-72.

6 W.G. Sebald Campo Santo, s. 233-234. 
Towarzyszący fragmentowi tekst każe wierzyć, że osobą sfotografowaną jest spotkany w Wiedniu Ernst Herbeck lub może dziadek narratora - „Na głowie miał mały kapelusz, coś w rodzaju trilby, który potem, gdy zrobiło mu się za gorąco, zdjął i niósł z boku, zupełnie tak samo jak kiedyś mój dziadek w czasie letnich spacerów"7. Tymczasem jest to nieco tylko podretuszowany wycinek znanej fotografii Roberta Walsera z okresu jego pobytu w zakładzie dla psychicznie chorych w Herisau, zapewne krótko przed śmiercią ${ }^{8}$. W ten sposób niejako całe pisarstwo Walsera staje się dla utworu Sebalda implikowanym intertekstem, a jeżeli tak, to pojawia się w niej tłumiony niepokój, tak charakterystyczny zwłaszcza dla krótkich próz autora Willi pod Gwiazda Wieczorna.Źródło tego niepokoju wskazał trafnie Elias Canetti: „Osobliwość Roberta Walsera polega na tym, że Walser nigdy nie wyznaje swoich motywów. To najbardziej skryty spośród poetów. Zawsze mu się dobrze dzieje, zawsze jest wszystkim zachwycony. Ale jego marzycielstwo tchnie chłodem [...]. Dla Walsera wszystko staje się zewnętrzną naturą, a tego co stanowi rdzeń natury, jej wnętrze - lęku - Walser przez całe życie się zapiera. [...] Jego twórczość to nieustanny wysiłek przemilczenia lęku"'. U Sebalda poziom napięcia wydaje się niższy - służy mu warstwa opisowa pozbawiona Walserowskiej ostentacji, pewnego łatwo wyczuwalnego nadmiaru entuzjazmu, sentymentalnej, choć podszytej ironią egzaltacji, a także częsty eseistyczny tok prezentacji faktów i spostrzeżeń, niemniej raz zakwestionowana uchwycona na fotografii powierzchnia świata traci swą wiarygodność i każe raz zwiedzionemu czytelnikowi podejrzewać fałszerstwo niemal na każdym kroku. Założona w akcie odbioru współpraca obrazu i komentarza nagle upada. Okazuje się, że komentarz może nie fair wykorzystywać pozornie niewinne przedstawienie wizualne do tworzenia iluzji niezgodnej z obietnicą referencyjnej prawdy właściwą przecież dla znaku ikonicznego. Zaryzykuję stwierdzenie, że strategię tę można odczytać jako szczególny wariant romantycznego motywu sobowtóra, znany m.in. z opowiadania Poego William Wilson. Fotografia świata wydaje się jego Doppelgängerem, ale nim nie jest. Jak u Poego, zagładzie ulega jedynie to, co "naprawdę" realne, o czym przekonuje Austerlitz i Wyjechali, a fotograficzne powtórzenie może równie dobrze okazać

7 W.G. Sebald Czuję.Zawrót głowy, przeł. M. Łukasiewicz, Wydawnictwo Literackie, Kraków 1998, S. 33 .

Odkrycie to zawdzięczam bezpośrednio Pani Małgorzacie Łukasiewicz.

E. Canetti Zapiski o Robercie Walserze, przeł. M. Łukasiewicz, w: M. Łukasiewicz Robert Walser, Czytelnik, Warszawa 1990, s. 98. 
się iluzją, płaszczyzną pozbawioną łączności ze wskazanym przez towarzyszący jej komentarz desygnatem.

$\mathrm{Z}$ drugiej jednak strony mamy również w prozie Sebalda do czynienia $\mathrm{z}$ nieustającym wysiłkiem stworzenia osobliwego archiwum historii i obrazów w rodzaju Atlasu obrazów Mnemosyne Aby'ego Warburga - repozytorium autobiografii, biografii i wizerunków świata, jaki jest całego tego wielokształtnego życia scenerią. Jak można opisać funkcjonowanie tego zasobu? $\mathrm{O}$ archiwum w kontekście relacji między psychoanalizą a historiografią pisze w Goraczce archiwum Jacques Derrida:

A zatem, jeśli chodzi o archiwum, Freud nigdy nie zdołał stworzyć czegoś, co zasługiwałoby na takie miano. Skądinąd my również tego nie zrobiliśmy. Nie dysponujemy pojęciem, jedynie impresją, serią impresji skojarzonych ze słowem. Przeciwstawiam tu ścisłość pojęcia niewyraźnemu charakterowi bądź otwartej nieokreśloności, idei tego rodzaju. "Archiwum" to jedynie idea, impresja połączona ze słowem, dla którego ani Freud, ani my nie możemy wynaleźć żadnego pojęcia. Mamy jedynie impresję, uporczywą impresję dostępną przez nietrwałe odczucie zmiennej figury schematu, czy też nie-skończonego lub nieokreślonego procesu. [...] Wynika z tego oczywiście, że Freudowska psychoanaliza proponuje nową teorię archiwum; bierze pod uwagę topikę i popęd śmierci, bez której nie byłoby w istocie żadnego pragnienia, ani żadnej możliwości dla archiwum. ${ }^{10}$

Jeżeli przyjąć na lokalny użytek, że owo Derridiańskie „my” obejmuje także Sebalda, to okaże się, że mimochodem powróciliśmy do post-Kantowskich dywagacji Lacoue-Labarthe'a i Nancy'ego na temat niemożliwości ukonstytuowania podmiotu jako pojęcia, ponieważ jest on tylko rozchwianym „podmiotem poznania zjawisk", poddanym w dodatku nieuchronności śmierci, przed którą usiłuje się nieudolnie bronić, opowiadając historie o innych, już zmarłych, lecz również o sobie, i uzupełniając je na próżno fotografiami. W tym miejscu - i to już jest prawie punkt ostatni, a raczej ostateczny, gdyż znana droga nie wiedzie nigdzie dalej - docieramy do postaci, która zdawała się przyciągać uwagę Sebalda szczególnie: do Sir Thomasa Browne'a, XVII-wiecznego angielskiego medyka i eseisty, autora m.in. dziełka Hydriotaphia.

10 J. Derrida Gorączka archiwum. Impresja freudowska, przeł. J. Momro, Wydawnictwo IBL PAN, Warszawa 2016, s. 46-47 
Pochówek urnowy albo, krótka rozprawa o urnach grobowych znalezionych ostatnio w Norfolk (1658). W zamykającym ją rozdziale V Browne rozważa daremną chęć upamiętnienia się na przekór śmierci, zwłaszcza poprzez imponujące budowle grobowe, takie „Piramidy, Łuki czy Obeliski”:

„Zapomnienie" - powiada z chrześcijańską pokorą - „nie daje się okiełznać. Większość musi pozostać kontenta, iż była, a jakoby jej nie było, skazana na zapis jeno w Rejestrach Bożych, nie zaś w księgach ludzkich. [...] Ciemność i światło dzielą przebieg czasu i zapomnienie przeplata się z pamięcią, grzebiąc wielką część naszego żywota: ledwie pamiętamy nasze uciechy, a i najgorsze przypadłości pozostawiają w nas tylko krótkotrwałe ślady. [...] Na próżno żywimy nadzieję na Nieśmiertelność bądź inne lekarstwo na zapomnienie, trwanie pod Księżycem: Ludzie nawet [...] obmyślali fortele, aby utrwalić swe imiona na Niebiesiech. Kosmografia zmieniła już nazwy wykoncypowanych niegdyś konstelacji: Nimrod przepadł w Orionie, a Ozyrys w Psiej Gwieździe"."

Słowem, żadne starania - żadne epitafia, mauzolea czy nagrobki - nie są w stanie zagwarantować podmiotowi przetrwania w pamięci. Nawet Musée Fesch, muzeum Napoleona w korsykańskim Ajaccio, sprawia bardzo skromne wrażenie, mimo że cesarz zrobił przecież aż nadto, by go zapamiętano w całej Europie. Wśród zebranych tam napoleońskich „dewocjonaliów” znajdują się, o czym powiadamia zwiedzający muzeum „Sebald”, liczne figurki bohatera, w tym także „Napoleon nie większy od ziarnka grochu, w płaszczu i trójgraniastym kapeluszu”, tkwiący „w pozycji kawaleryjskiej na stołeczku, który umieszczony jest na czubku faktycznie pochodzącego z wyspy [św. Heleny] odłamka tufu i ze zmarszczoną brwią [patrzący - przy. M.W.] w dal"12. Ujeżdżający taboret miniaturowy l'Empereur to niezamierzone arcydzieło historycznej ironii, efekt szyderczego odwrócenia perspektywy. Przez tekstową lunetę ledwo go widać, a może na odwrót - bardzo rzuca się w oczy, gdyż stanowi doskonałe przeciwieństwo posągowej postaci spod Jeny i Auerstädt, jak gdyby jenajska ironia Friedricha Schlegla dopadła go po śmierci w utrwalonym marsowym grymasie ujawniającym całą swą absurdalność. Ten Napoleon to zminiaturyzowana ruina człowieka, a ruiny to jeszcze jeden

11 T. Browne The Major Works, ed. By C.A. Patrides, Penguin, Harmondsworth 1977, s. 310-312 [przekład polski - M.W.]. 
romantyczny motyw, który po cichu Sebalda fascynuje. Przekonuje o tym dobitnie początek rozdziału drugiego Pierścieni Saturna, kiedy narrator, wędrując po regionie East Anglia, dociera do starożytnej posiadłości Somerleyton o przeszłości sięgającej średniowiecza. Rezydencja długo przechodziła z rąk do rąk przedstawicieli znamienitych rodów, aż wreszcie w roku 1834 jej właścicielem został „niejaki sir Morton Peto, który wywodził się z nizin społecznych i zaczynał jako prosty robotnik i pomocnik murarski" ${ }^{\prime 13}$. Doprowadził on podupadłą siedzibę do rozkwitu: dzięki zdobytej fortunie „wystawił książęcy pałac w stylu angielsko-włoskim", lecz budowla przetrwała znacznie krócej niż jej mniej imponująca poprzedniczka: „Dziś Somerleyton nie robi już wrażenia orientalnego pałacu z bajki. Oszklone galerie i palmiarnia, której wyniosła kopuła niegdyś rozświetlała noce, zostały zniszczone już w 1913 roku przez eksplozję gazu, a następnie rozebrane, służbę utrzymującą wszystko w należytym porządku, butlerów, stangretów, szoferów, ogrodników, kucharki, szwaczki i pokojówki dawno zwolniono"14. Pozostały zaniedbane resztki dawnej świetności, a oprowadza po nich, niczym żywa karykatura przodków, „konduktor, maszynista i pogromca zwierząt w jednej osobie - obecny lord Somerleyton, Her Majesty's The Queen's Master of the Horse"15.

Narratorowi jednak podoba się to, co zobaczył: „I jaka piękna wydawała mi się ta rezydencja teraz, gdy niepostrzeżenie zbliżała się do rozpadu i upodobniała do cichej ruiny". Niestety owo zapowiadające się dopiero piękno ruin, opiewane przez Constantina-François Volneya u zarania romantyzmu (1791) w słynnym wówczas dziele Les Ruines, ou Méditations sur les révolutions des empires, w następnym zdaniu nagle gaśnie, zderzone z koszmarnym obrazem ptaka beznadziejnie uwięzionego w klatce: „Z drugiej strony jednak przygnębiło mnie, kiedy zwiedziwszy dom od wewnątrz, wyszedłem znów na dwór, by obejrzeć w jednej z wolier, przeważnie już pustych, samotną chińską przepiórkę, która - najwyraźniej w stanie demencji - biegała bez ustanku wzdłuż prawej ściany klatki i za każdym razem, gdy już miała zawrócić, potrząsała głową, jak gdyby nie pojmując, jakim sposobem znalazła się w tej beznadziejnej sytuacji"16. Nieszczęsna przepiórka wyraźnie przypomina człowieka, a przynajmniej opisana jest w swej uderzająco ludzkiej „demencji” tak,

\footnotetext{
13 W.G. Sebald Pierścienie Saturna, s. 40.

14 Tamże, s. 43.

15 Tamże, s. 39.

16 Tamże, s. 45.
} 
jakby była okrutnie przemienioną lokatorką domu starców lub pacjentką szpitala dla nerwowo chorych w dawnym stylu. W tym momencie cały urok Somerleyton zostaje nieodwołalnie zniweczony: ruina ptasia unieważnia romantyczny potencjał miejsca, z którego nietknięty pozostaje tylko wciąż żywy na przekór historii park otaczający pałac.

Romantyczny temat ruin pojawia się jednak u Sebalda na największą skalę nie w prozie na pograniczu fikcji, lecz w pozbawionym wszelkich kategorialnych ambiwalencji eseju. Esej ten to Wojna powietrzna i literatura, zapis wykładów wygłoszonych przez pisarza w Zurychu jesienią roku 1997, opublikowany dwa lata później. Już pierwsze zdanie porusza przy tym inny typowo romantyczny problem, a mianowicie ograniczone możliwości przedstawienia pewnego rodzaju wydarzeń, skutkujące doznaniem kantowskiej wzniosłości: „Uczucie wzniosłości jest więc uczuciem przykrości wypływającym z nieodpowiedniości naszej wyobraźni w jej estetycznej ocenie wielkości do oceny dokonywanej przez rozum [...]"17. W przypadku Sebalda chodzi o wielkość, którą Kant byłby zapewne skłonny zakwalifikować jako „monstrualność (Unhegeuer)"18 i która w ramach rozwiniętych w Krytyce władzy sądzenia refleksji lokuje się nie tylko poza granicami wyobraźni, lecz również poznania rozumowego. Owo pierwsze zdanie brzmi tak: „Trudno dziś choćby w przybliżeniu wyrobić sobie wyobrażenie o rozmiarach spustoszenia niemieckich miast w ostatnich latach drugiej wojny światowej, a jeszcze trudniej zastanawiać się nad związaną z tymi spustoszeniami grozą"19. Ruiny, w jakie zmasowane alianckie bombardowania obróciły Drezno, Monachium, Kolonię, Hamburg, Bremę i wiele innych miejscowości, nie nastroiły bynajmniej obserwujących je niemieckich pisarzy do melancholijnej medytacji nad zmiennymi kolejami dziejów obfitujących w upadki imperiów, stając się poprzez swe rozmiary specyficznym parawanem przysłaniającym śmierć setek tysięcy ludzi.„Nawet okrzyczana, programowo deklarująca bezkompromisowy realizm literatura ruin”, ciągnie Sebald, „[...] przy bliższym wejrzeniu okazuje się dostrojonym do indywidualnej i zbiorowej amnezji, zapewne sterowanym podświadomymi procesami autocenzury instrumentem, służącym zawoalowaniu tego, co przekracza wszelkie pojęcie. Milcząco zawarty i wszystkich na równi obowiązujący pakt nie zezwalał na opisywanie prawdziwego stanu materialnej

\footnotetext{
I. Kant Krytyka władzy sadzenia, przeł. J. Gałecki, PWN, Warszawa 1964, s. 152.

Por. tamże, s. 144 .

W.G. Sebald Wojna powietrzna i literatura, przeł. M. Łukasiewicz, W.A.B., Warszawa 2012, s. 11.
} 
i moralnej destrukcji, która ogarnęła cały kraj"20 . Abstrahując od kwestii niemieckiej odpowiedzialności za wybuch i przebieg II wojny światowej, autor Wojny powietrznej staje w obliczu niepamięci zniszczeń i ofiar wśród ludności cywilnej, aby wskazać na niedający się ogarnąć rozmiar cierpienia spektakularnie ukrytego pod gigantycznymi spustoszeniami. W jego perspektywie stają się one znakiem negacji śmierci - wyeliminowania jej z obszaru możliwej do wysłowienia refleksji, która mogłaby nas czegoś istotnego nauczyć.

Tendencja do eliminowania śmierci i pamięci o niej trwa do dzisiaj co więcej, zdaniem Sebalda w dobie ponowoczesnej gwałtownie narasta: „Zmarli są jeszcze wokół nas, ale czasem wydaje mi się, że wkrótce może znikną. [...] Ich znaczenie wyraźnie słabnie. O wiecznej pamięci i kulcie zmarłych nie może już być mowy. Przeciwnie, zmarłych trzeba jak najszybciej i gruntownie usuwać na bok". Naszym signum temporis jest zatem śmierć do drugiej potęgi, społeczna śmierć śmierci, wypływająca ze wspieranego przez medycynę i przemysł kosmetyczny powszechnego marzenia o urzeczywistnionej nieśmiertelności, która zarazem unicestwia sens życia określany dotąd przez horyzont odejścia. „Komu na uroczystości żałobnej w krematorium, gdy trumna na lawecie wjeżdża do komory spalania, nie przyszłoby do głowy, że sposób, w jaki rozstajemy się ze zmarłymi, odznacza się nieudolnie skrywanym skąpstwem i pośpiechem? Zmarłym przydziela się też coraz mniej miejsca, a często, nim minie parę lat, znowu cofa się przydział" ${ }^{21}$. Warunki gospodarowania przestrzenią, zwłaszcza w wielkich miastach, sprzyjają dziś przede wszystkim przedsiębiorcom budowlanym - logice „development”, czyli dosłownie "rozwoju” wbrew jego ograniczeniom, także tym naturalnym, związanym ze starzeniem się ciała i kapitulacją komórek. Sebald opisuje i ostrzega „[...] w metropoliach końca dwudziestego wieku, gdzie każdego w jednej chwili da się zastąpić i każdy właściwie już od urodzenia jest nadliczbowy, chodzi o to, by na bieżąco pozbywać się balastu, a o wszystkim, co można by zatrzymać w pamięci, jak młodość, dzieciństwo, pochodzenie, dziadkowie i przodkowie, doszczętnie zapominać" 22 . Wszystko, co wiąże się z przeszłością, lawinowo traci znaczenie, ponieważ przysługuje ono jedynie teraźniejszości, chwili obecnej, którą pragniemy po faustowsku utrwalić, zapominając, że będzie to drogo kosztowało: „[...] w pozbawionej pamięci

Tamże, s. 18 .

W.G. Sebald Campo Santo, s. 40. 
teraźniejszości i w obliczu nieuchwytnej już dla jednostkowego rozumu przyszłości na koniec będziemy porzucali życie, nie czując potrzeby, by dano nam przynajmniej chwilę jeszcze pozostać albo przy okazji powrócićn"23.

Paradoksalnej obronie „tradycyjnej” śmierci - a śmierć to wszak również jeden z kluczowych tematów romantycznych - towarzyszy u Sebalda apologia wagi historii nieco w duchu konserwatywnego romantyzmu Edmunda Burke’a oraz angielskich miłośników średniowiecza. Historia, nie tylko zbiorowa i monumentalna, ale także - w szczególności - prywatna i w skali mikro, winna pozostać przedmiotem indywidualnej pamięci, gdyż wspiera podmiot w jego niepewnym, chybotliwym byciu. Inaczej przestanie on rozumieć przestrzeń, w której wędruje, nawet jeśli czasem odbywa swoje wędrówki tylko w wyobraźni - od Berdyczowa i Krakowa po Antwerpię, Norwich i Somerleyton. Nie będzie mógł też powrócić jako revenant, czyli upiór, kolejna romantyczna figura nawiedzająca tu i ówdzie prozę Sebalda. Dlatego niepokoi go modny „pochówek urnowy”, redukujący doczesne szczątki tak radykalnie, że tracimy okazję do wykorzystania repertuaru upamiętnień, od pomników nagrobnych po epitafia, mimo że na dobrą sprawę nie gwarantują one niczego i zdradzają dozę próżności. Tak czy inaczej, kiedy już zdarzy nam się atak serca tuż przy wjeździe na autostradę, pozostanie literatura, o ile, tak jak W.G. Sebald, potrafimy ją pisać - i czytać. 


\section{Abstract}

\section{Marek Wilczyński}

UNIVERSITY OFWARSAW

W.G. Sebald, the Romantic Subject

This paper addresses the construction of subjectivity in W.G. Sebald's quasiautobiographical writings, Vertigo, The Rings of Saturn, and Campo Santo. The fragmentary nature and ambiguous ontological status of the subject in Sebald's prose allow him to associate it with the poetics of German Romanticism of the Jena circle, which defined subjectivity as a pure imagination that only synthesises experience. Sebald's reported experience includes travels, reading and characters found in books, as well as reflections on the impossibility of representing mass destruction and death. The problem of subjectivity is made even more complicated by the use of photographs, which suggests the truth of visual perception although some of the persons or objects in the photographs do not correspond to their descriptions.

\section{Keywords}

subjectivity, imagination, archive, photography, sublime 